\title{
Responses of Cherry Plant Grafted onto CAB-6P, MaxMa 14 and Mazzard Rootstocks to Short Term Salinity
}

\author{
Servet Aras (Corresponding author) \\ Faculty of Agriculture, Department of Horticulture, Yozgat Bozok University \\ PO Box 66200, Yozgat, Turkey \\ E-mail: servet.aras@bozok.edu.tr
}

\begin{abstract}
Ahmet Eşitken
Faculty of Agriculture, Department of Horticulture, Selcuk University

Konya, Turkey

E-mail: aesitken@selcuk.edu.tr
\end{abstract}

Received: June 23, $2019 \quad$ Accepted: July 9, $2019 \quad$ Published: July 18, 2019

doi:10.5296/jas.v7i3.15114

URL: https://doi.org/10.5296/jas.v7i3.15114

\begin{abstract}
Salt stress is a common environmental challenge that adversely affects plant growth. However, little is known about the responses of plants to short term salinity. In the current experiment, we investigated morphological and physiological responses of a cherry cultivar (0900 Ziraat) grafted onto three rootstocks (CAB-6P, MaxMa 14 and Mazzard) to $35 \mathrm{mM}$ $\mathrm{NaCl}$ stress. After one month, salt stress decreased plant growth of cherry plants. Rootstock, scion and shoot diameters and shoot length significantly decreased with salinity. The higher decrease in membrane permeability under salt stress was found in 0900/MaxMa 14 by $41 \%$. 0900/Mazzard had the highest decline in LRWC by $15 \%$. The results obtained demonstrate that a higher tolerance to short term salt stress was found in 0900 Ziraat grafted onto Mazzard is associated with: lower depression in plant growth, less decrease in chlorophyll content and more stability in cell membranes determined in membrane permeability measurement. Furthermore, the results showed that in the short term, cherry can be considered salt tolerant.
\end{abstract}

Keywords: cherry, plant growth, rootstock, salt stress 


\section{Introduction}

Salinity is one of the major problems worldwide, especially in seashore lands and poor drained areas with excessive fertilization. Salt stress causes a decrease in fruit yield and quality in many fruit crops. Many temperate zone fruit trees are susceptible to salt stress (Okubo et al., 2000; Yin et al., 2010; Aras \& Eşitken, 2019). The effects of salinity on plant growth, cellular damage and dysfunction in nutrient uptake have been reported in a number of fruit crops, including strawberry (Aras \& Eşitken, 2018), apple (Fu et al., 2013; Aras \& Eşitken, 2019), pear (Okubo et al., 2000). Salt stress induces disruption in water relations, gas exchanges and ion uptake (Munns \& Tester, 2008; Sabra et al., 2012).

Managers for cherry must deal with salinity damages. One of the most promising avenues for improving plant tolerance against salinity is the use of the salt-tolerant rootstocks. To survive under salt stress, plants reveal some defense mechanisms to minimize possible damages. These include an adjustment in nutrient uptake, alterations in metabolisms, increase in root growth (Sotiropoulos et al., 2006; Yin et al., 2010). Therefore, the proper choice of rootstock is fundamental for increasing salinity tolerance. Yin et al. (2010) evaluated many apple rootstocks under salinity. They reported growth parameters such as leaf number, plant height decreased and membrane permeability of the cells increased under salinity condition. In a previous experiment, we assessed an apple cultivar Fuji grafted onto two common used rootstocks (M9 and MM106) under short term salinity (for one month). We suggested that toxic effects of salinity for one month were less in Fuji/M9 due to less decrease in relative chlorophyll content, stomatal conductance and leaf water content (Aras \& Eşitken, 2019). In another study, the responses of cherry cv. 0900 Ziraat grafted onto mazzard and mahaleb rootstocks were investigated. The authors reported that salt stress caused more damage on 0900/mazzard (Küçükyumuk et al., 2015).

Differences in the degree of tolerance to long term salinity among rootstocks have been investigated in temperate zone fruit trees (García-Legaz et al., 2008; Zrig et al., 2011; Akçay \& Eşitken, 2017). However, limited information is available on the short term salinity damage. The objective of the current study was to investigate the morphological and physiological responses of the cherry cultivar (0900 Ziraat) grafted onto three common rootstocks to short term salt stress. Understanding the responses of cherry plant against salt stress will be crucial for regional recommendations for cherry growers.

\section{Materials and Methods}

The study was conducted between 2015 and 2016 in a heated greenhouse of the Department of Horticulture at Selcuk University in Turkey. One-year-old sweet cherry cultivar "0900 Ziraat" grafted onto Mazzard, MaxMa 14 and CAB-6P rootstocks were grown in $13 \mathrm{~L}$ pots filled with a mixture of soil, substrate and perlite in a volume proportion of 1:3:1. Up until the start of the experiment, all plants were irrigated with tap water and then the duration of the experiment treated plants were watered with fertilizer solution containing $35 \mathrm{mM} \mathrm{NaCl}$ and untreated plants as control group were watered with fertilizer solution without $\mathrm{NaCl}$ during a month. Excess solution was allowed to drain from the pot. The experiment was carried out following a randomized plot design involving three replications, with 5 plants per replication. 
Rootstock, scion and shoot diameters were measured with a digital caliper. Shoot length was measured with a ruler.

Relative chlorophyll value was measured with a Minolta SPAD-502 chlorophyll meter (Minolta Camera Co, Ltd, Osaka, Japan). Stomatal conductivity and leaf temperature measurements were conducted on the youngest fully expanded leaves on upper branches of the plants with leaf porometer.

The procedure of electrolyte leakage based on Lutts et al. (1996) was used to assess membrane permeability. Electrolyte leakage was measured using electrical conductivity (EC) meter. Mature leaves per plant were taken and cut into $1 \mathrm{~cm}$ segments. Leaf samples were then placed in individual stoppered vials containing $10 \mathrm{~mL}$ of distilled water after three washes with distilled water for removing surface contamination. These samples were incubated at room temperature $\left(25^{\circ} \mathrm{C}\right)$ on a shaker $(100 \mathrm{rpm})$ for $24 \mathrm{~h}$. Electrical conductivity (EC) of bathing solution $\left(\mathrm{EC}_{1}\right)$ was measured after incubation. The same samples were then placed in an autoclave at $120^{\circ} \mathrm{C}$ for $20 \mathrm{~min}$ and the second measurement $\left(\mathrm{EC}_{2}\right)$ was taken after cooling solution to room temperature. The electrolyte leakage was calculated as $\mathrm{EC}_{1} / \mathrm{EC}_{2}$ and expressed as a percent.

Leaf relative water content (LRWC) was determined by the procedure of Smart and Bingham (1974). Leaves were collected from the young fully expanded leaves of three plants per replicate. Individual leaves first detached from the stem and then weighted to determine fresh weight $(\mathrm{FW})$. In order to determine the turgid weight (TW), leaves were floated in distilled water inside a closed petri dish. Leaf samples were weighted periodically, after gently wiping the water from the leaf surface with the tissue paper until a steady state was achieved. At the end of the imbibition period, leaf samples were placed in a pre-heated oven at $72^{\circ} \mathrm{C}$ for $48 \mathrm{~h}$, in order to determine the dry weight (DW). Values of FW, TW, and DW were used to calculate LRWC using the equation given below:

$$
\mathrm{LRWC}(\%)=[(\mathrm{FW}-\mathrm{DW}) /(\mathrm{TW}-\mathrm{DW})] \times 100
$$

Statistical analyses were performed with the statistical software package SPSS, version 20.0. The means were compared by one-way ANOVA test at 5\% significance. Average of the data belonging two consecutive years were analyzed.

\section{Results}

The differences in the morphological parameters were found among scion-rootstock combinations. Two years of the study showed that the parameters were significantly affected by salt stress. A higher reduction in rootstock diameter was in 0900/MaxMa 14 by 14\% compared with own control (Table 1). The highest decrease in scion diameter was found in 0900 Ziraat cv. grafted onto mazzard rootstock. 0900/MaxMa had the highest decrease (14\%) in shoot diameter, while the lowest reduction in shoot length (3\%) was in 0900/MaxMa. 
Table 1. Effects of salinity on morphological responses of cherry plants

\begin{tabular}{llllll}
\hline Variety/Rootstock & Treatments & $\begin{array}{l}\text { Rootstock } \\
\text { diameter } \\
(\mathrm{mm})\end{array}$ & $\begin{array}{l}\text { Scion } \\
\text { diameter } \\
(\mathrm{mm})\end{array}$ & $\begin{array}{l}\text { Shoot } \\
\text { diameter } \\
(\mathrm{mm})\end{array}$ & $\begin{array}{l}\text { Shoot } \\
\text { length }(\mathrm{cm})\end{array}$ \\
\hline 0900/CAB-6P & Control & $16.5 \mathrm{a}$ & $12.4^{\mathrm{NS}}$ & $4.3 \mathrm{a}$ & $26.6 \mathrm{a}$ \\
& $35 \mathrm{mM} \mathrm{NaCl}$ & $14.9 \mathrm{~b}$ & 11.5 & $3.7 \mathrm{~b}$ & $22.4 \mathrm{~b}$ \\
0900/MaxMa14 & Control & $18.5 \mathrm{a}$ & $13.5 \mathrm{a}$ & $4.9 \mathrm{a}$ & $31.5^{\mathrm{NS}}$ \\
& $35 \mathrm{mM} \mathrm{NaCl}$ & $15.9 \mathrm{~b}$ & $11.9 \mathrm{~b}$ & $4.2 \mathrm{~b}$ & 30.6 \\
& Control & $17.4 \mathrm{NS}$ & $12.6 \mathrm{a}$ & $3.8^{\mathrm{NS}}$ & $23.2 \mathrm{a}$ \\
\hline
\end{tabular}

Means separation within the columns by Duncan's multiple range test. $\mathrm{P}<0.05$, NS: Non-Significant

The highest reduction in SPAD value was found in 0900/MaxMa 14 by 13\% (Table 2). There was no great decline found in stomatal conductance. In saline treated 0900/MaxMa 14, there was a decline in stomatal conductance by $19 \%$ compared to the control. The leaf temperature was not significantly affected. The higher decrease in membrane permeability under salt stress was found in 0900/MaxMa 14 by 41\%. 0900/Mazzard had the highest decline in LRWC by $15 \%$. 
Table 2. Effects of salinity on physiological responses of cherry plants

\begin{tabular}{|c|c|c|c|c|c|c|}
\hline Variety/Rootstock & Treatments & SPAD & $\begin{array}{l}\text { Stomatal } \\
\text { conductance } \\
(\mathrm{mmol} \\
\left.\mathrm{m}^{-2} \mathrm{~s}^{-1}\right)\end{array}$ & $\begin{array}{l}\text { Leaf } \\
\text { temperature } \\
\left({ }^{\circ} \mathrm{C}\right)\end{array}$ & $\begin{array}{l}\text { Membrane } \\
\text { permeability } \\
(\%)\end{array}$ & $\begin{array}{l}\text { LRWC } \\
(\%)\end{array}$ \\
\hline \multirow[b]{2}{*}{ 0900/CAB-6P } & Control & $36.5 \mathrm{a}$ & $198.1^{\mathrm{NS}}$ & $31.4^{\mathrm{NS}}$ & $22.7 \mathrm{~b}$ & $76.0 \mathrm{a}$ \\
\hline & $\begin{array}{ll}35 & \mathrm{mM} \\
\mathrm{NaCl} & \end{array}$ & $\begin{array}{l}32.4 \\
b\end{array}$ & 182.6 & 31.4 & $26.6 \mathrm{a}$ & $66.7 \mathrm{~b}$ \\
\hline \multirow[b]{2}{*}{ 0900/MaxMa14 } & Control & $32.9 \mathrm{a}$ & $241.0 \mathrm{a}$ & $31.5^{\mathrm{NS}}$ & $21.9 \mathrm{~b}$ & $73.2 \mathrm{a}$ \\
\hline & $\begin{array}{ll}35 & \mathrm{mM} \\
\mathrm{NaCl} & \end{array}$ & $\begin{array}{l}28.5 \\
b\end{array}$ & $196.3 \mathrm{~b}$ & 31.9 & $30.9 \mathrm{a}$ & $68.7 \mathrm{~b}$ \\
\hline \multirow[b]{2}{*}{ 0900/Mazzard } & Control & $\begin{array}{l}34.1 \\
\text { NS }\end{array}$ & $259.3 \mathrm{a}$ & $28.7^{\mathrm{NS}}$ & $22.9^{\mathrm{NS}}$ & $77.4 \mathrm{a}$ \\
\hline & $\begin{array}{ll}35 & \mathrm{mM} \\
\mathrm{NaCl} & \end{array}$ & 31.7 & $221.3 b$ & 28.1 & 26.0 & $65.9 \mathrm{~b}$ \\
\hline
\end{tabular}

Means separation within the columns by Duncan's multiple range test. $\mathrm{P}<0.05$, NS: Non-Significant

\section{Discussion}

Our experiment exhibited that the extent of depression in plant growth and alterations in the physiology of cherry plants were dependent on the rootstock under salinity stress condition. Leaf injury was not observed in salt-treated plants after one month of the treatment. Musacchi et al. (2006) reported that pear, a temperate zone tree, is not very sensitive to short term salinity and did not show any symptom of salt damage. Differences in salt tolerance based on rootstock are considered to be associated with defense mechanisms to survive. Our results are in agreement with previous experiments in which salt stress adversely affected plant growth and physiology (Okubo et al., 2000; García-Legaz et al., 2008).

Salt stress causes a decrease in the plant growth in both herbaceous (Koc et al., 2016a,b; Civelek and Y1ldırım, 2019) and woody plants (Simpson et al., 2014; Papadakis et al., 2018). Changes in plant growth depression may reflect their tolerance to salt stress. In our study, rootstock, scion and shoot diameters and shoot length decreased under salt stress. 0900 Ziraat grafted onto MaxMa 14 showed the highest decreases in rootstock and shoot diameters by 14 and $14.2 \%$, respectively, while 0900/Mazzard had the lowest declines in rootstock and shoot diameters by 9.2 and $11 \%$, respectively. Significant reductions in shoot length and scion diameter as obtained here have been reported in apple (Yin et al., 2010), peach (Ye et al., 2016) and pear and quince (Musacchi et al., 2006). The decline in the plant growth would be a result of restriction in nutrient uptake due to the salt ( $\mathrm{Hu} \&$ Schmidhalter, 2005; García-Caparrós et al., 2016) that limits photosynthesis consequently decreases plant tissue 
extension. In the current study, the growth of Mazzard rootstock was less damaged compared to CAB- 6P and MaxMa 14.

SPAD value reflects chlorophyll content which pigment takes a pivotal role in the photosynthesis. The decline in chlorophyll content due to salinity has been reported in many plants (Papadakis et al., 2007; Aras \& Eşitken, 2019). The decrease in chlorophyll could be due to the salt that leads impairment in chlorophyll biosynthesis (Husaini \& Abdin, 2008). In the present experiment, 0900/Mazzard showed the lowest decrease in chlorophyll content by $7 \%$ under salinity that could be due to its greater maintenance of chlorophyll levels or inhibition of chlorophyllase activity which is responsible for chlorophyll degradation (Hanafy et al., 2002; Garriga et al., 2015).

The decline in stomatal conductance is a defense mechanism against salt stress to decrease water loss and reduce the salt uptake into the leaves (Everard et al., 1994; García-Legaz et al., 2008). Salinity reduced stomatal aperture in all plants and the higher loss in stomatal conductance was found in 0900/MaxMa 14 by $19 \%$. Higher decreases in chlorophyll and stomatal conductance may represent greater depressed in photosynthesis and consequently plant growth in 0900/MaxMa 14. Related with stomatal closure, lower reduction in LRWC was obtained in 0900/MaxMa 14 probably due to the less water loss through stomata. The decrease in LRWC under salt stress condition has been stated in many papers (Yin et al., 2010; Fu et al., 2013).

Salinity damage to membranes was measured by determination of membrane permeability. Cell membrane stability and permeability are thought to be a predictor of tolerance against stress factors. The stability of cell membranes represents plant resistance to stressors (Yin et al., 2010; Aras \& Eşitken, 2019). Salt stress increased membrane permeability by 17, 41 and $13 \%$ in 0900 Ziraat grafted onto CAB-6P, MaxMa 14 and Mazzard, respectively. Obtaining lower membrane permeability is related with salt tolerance reported in many experiments (Bolat et al., 2006; Ye et al., 2016).

\section{Conclusion}

We addressed for the first time to understand the effect of short term salt stress on cherry plants. We have shown the declines in plant growth in response to salt stress compared among three common rootstocks. The results demonstrated that in the short term, cherry can be considered salt tolerant. Long term responses of cherry trees to salt stress may be different due to the salt accumulation in leaves. We showed that different rootstocks revealed different responses against salt stress and Mazzard was less damaged compared to $\mathrm{CAB}-6 \mathrm{P}$ and MaxMa 14 for one month salinity.

\section{Acknowledgement}

This study was supported by grants from University of Selcuk with OYP Research Programme. 


\section{References}

Akçay, D., \& Eşitken, A. (2017). MM106 Anacı ve Üzerine Aş11 Golden Delicious Elma Çeşidine Tuz Stresinin Etkileri. Selçuk Tarım Bilimleri Dergisi, 3(2), 228-232.

Aras, S., \& Eşitken, A. (2019). Responses of Apple Plants to Salinity Stress. Yüzüncü Yıl University Journal of Agricultural Science, 29 (2), 253-257.

https://doi.org/10.29133/yyutbd.494677

Aras, S., \& Eşitken, A. (2018). Effects of silicon to salt stress on strawberry plant. Harran Journal of Agricultural and Food Science, 22(4), 478-483.

Bolat, I., Kaya, C., Almaca, A., \& Timucin, S. (2006). Calcium sulfate improves salinity tolerance in rootstocks of plum. Journal of Plant Nutrition, 29(3), 553-564.

https://doi.org/10.1080/01904160500526717

Civelek, C., \& Y1ldırım, E. (2019). Effects of Exegenous Glycine Betaine Treatments on Growth and Some Physiological Characteristics of Tomato under Salt Stress Condition. Atatürk Üniversitesi Ziraat Fakültesi Dergisi, 50(2), 153-158.

https://doi.org/10.17097/ataunizfd.520407

Everard, J. D., Gucci, R., Kann, S. C., Flore, J. A., \& Loescher, W. H. (1994). Gas exchange and carbon partitioning in the leaves of celery (Apium graveolens L.) at various levels of root zone salinity. Plant Physiology, 106(1), 281-292. https://doi.org/10.1104/pp.106.1.281

Fu, M., Li, C., \& Ma, F. (2013). Physiological responses and tolerance to $\mathrm{NaCl}$ stress in different biotypes of Malus prunifolia. Euphytica, 189(1), 101-109.

https://doi.org/10.1007/s10681-012-0721-1

García-Caparrós, P., Llanderal, A., Pestana, M., Correia, P. J., \& Lao, M. T. (2016). Tolerance mechanisms of three potted ornamental plants grown under moderate salinity. Scientia Horticulturae, 201, 84-91. https://doi.org/10.1016/j.scienta.2016.01.031

García-Legaz, M. F., López-Gómez, E., Beneyto, J. M., Navarro, A., \& Sánchez-Blanco, M. J. (2008). Physiological behaviour of loquat and anger rootstocks in relation to salinity and calcium addition. Journal of Plant Physiology, 165(10), 1049-1060.

https://doi.org/10.1016/j.jplph.2007.07.022

Garriga, M., Muñoz, C. A., Caligari, P. D., \& Retamales, J. B. (2015). Effect of salt stress on genotypes of commercial (Fragaria x ananassa) and Chilean strawberry (F. chiloensis). Scientia Horticulturae, 195, 37-47. https://doi.org/10.1016/j.scienta.2015.08.036

Hanafy, A. H., Gad-Mervat, M. A., Hassam, H. M., \& Amin-Mona, A. (2002). Improving growth and chemical composition of Myrtus communis grown under soil salinity conditions by polyamine foliar application. In: Proceedings of the Minia 1st Conference Agriculture Environment Science Minia, March 25-28, Egypt, 1697-1720.

Hu, Y., \& Schmidhalter, U. (2005). Drought and salinity: a comparison of their effects on mineral nutrition of plants. J. Plant Nutr. Soil Sci., 168, 541-549. 
https://doi.org/10.1002/jpln.200420516

Husaini, A. M., \& Abdin, M. Z. (2008). Overexpression of tobacco osmotin gene leads tosalt stress tolerance in strawberry (Fragariaxananassa Duch.) plants. Indian J. Biotechnol., 7, 465-471.

Koc, A., Balci, G., Erturk, Y., Dinler, B. S., Keles, H., \& Bakoğlu, N. (2016a). Farkl1 tuz konsantrasyonlarının ve uygulamaların çilek gelişimi üzerine etkileri. Journal of Ataturk Central Horticultural Research Institute, 45, 468-473.

Koc, A., Balci, G., Erturk, Y., Keles, H., Bakoglu, N., \& Ercisli, S. (2016b). Influence of arbuscular mycorrhizae and plant growth promoting rhizobacteria on proline, membrane permeability and growth of strawberry (Fragaria x ananassa) under salt stress. Journal of Applied Botany and Food Quality, 89, 89-97.

Küçükyumuk, C., Yildiz, H., Küçükyumuk, Z., \& Ünlükara, A. (2015). Responses of '0900 Ziraat' Sweet Cherry Variety Grafted on Different Rootstocks to Salt Stress. Notulae Botanicae Horti Agrobotanici Cluj-Napoca, 43(1), 214-221.

https://doi.org/10.15835/nbha.43.1.9754

Munns, R., \& Tester, M. (2008). Mechanisms of salinity tolerance. Annu. Rev. Plant Biol., 59, 651-681. https://doi.org/10.1146/annurev.arplant.59.032607.092911

Musacchi, S., Quartieri, M., \& Tagliavini, M. (2006). Pear (Pyrus communis) and quince (Cydonia oblonga) roots exhibit different ability to prevent sodium and chloride uptake when irrigated with saline water. European journal of Agronomy, 24(3), 268-275.

https://doi.org/10.1016/j.eja.2005.10.003

Okubo, M., Furukawa, Y., \& Sakuratani, T. (2000). Growth, flowering and leaf properties of pear cultivars grafted on two Asian pear rootstock seedlings under $\mathrm{NaCl}$ irrigation. Scientia Horticulturae, 85(1-2), 91-101.

Papadakis, I. E., Veneti, G., Chatzissavvidis, C., \& Therios, I. (2018). Physiological and growth responses of sour cherry (Prunus cerasus L.) plants subjected to short-term salinity stress. Acta Botanica Croatica, 77(2), 197-202. https://doi.org/10.2478/botcro-2018-0012

Papadakis, I. E., Veneti, G., Chatzissavvidis, C., Sotiropoulos, T. E., Dimassi, K. N., \& Therios, I. N. (2007). Growth, mineral composition, leaf chlorophyll and water relationships of two cherry varieties under NaCl-induced salinity stress. Soil Science and Plant Nutrition, 53(3), 252-258. https://doi.org/10.1111/j.1747-0765.2007.00130.x

Sabra, A., Daayf, F., \& Renault, S. (2012). Differential physiological and biochemical responses of three Echinacea species to salinity stress. Scientia Horticulturae, 135, 23-31. https://doi.org/10.1016/j.scienta.2011.11.024

Simpson, C. R., Nelson, S. D., Melgar, J. C., Jifon, J., King, S. R., Schuster, G., \& Volder, A. (2014). Growth response of grafted and ungrafted citrus trees to saline irrigation. Scientia Horticulturae, 169, 199-205. https://doi.org/10.1016/j.scienta.2014.02.020 


\section{Macrothink}

Sotiropoulos, T. E., Dimassi, K. N., Tsirakoglou, V., \& Therios, I. N. (2006). Responses of two Prunus rootstocks to $\mathrm{KCl}$ induced salinity in vitro. Biologia Plantarum, 50(3), 477-480. https://doi.org/10.1007/s10535-006-0075-4

Ye, J. B., Chen, Q. W., Tao, T. T., Wang, G., \& Xu, F. (2016). Promotive effects of 5-aminolevulinic acid on growth, photosynthetic gas exchange, chlorophyll, and antioxidative enzymes under salinity stress in Prunus persica (L.) Batseh seedling. Emirates Journal of Food and Agriculture, 786-795. https://doi.org/10.9755/ejfa.2016-06-647

Yin, R., Bai, T., Ma, F., Wang, X., Li, Y., \& Yue, Z. (2010). Physiological responses and relative tolerance by Chinese apple rootstocks to $\mathrm{NaCl}$ stress. Scientia Horticulturae, 126(2), 247-252. https://doi.org/10.1016/j.scienta.2010.07.027

Zrig, A., Tounekti, T., Vadel, A. M., Mohamed, H. B., Valero, D., Serrano, M., Chtara, C., \& Khemira, H. (2011). Possible involvement of polyphenols and polyamines in salt tolerance of almond rootstocks. Plant Physiology and Biochemistry, 49(11), 1313-1322.

https://doi.org/10.1016/j.plaphy.2011.08.009

\section{Copyright Disclaimer}

Copyright for this article is retained by the author(s), with first publication rights granted to the journal.

This is an open-access article distributed under the terms and conditions of the Creative Commons Attribution license (http://creativecommons.org/licenses/by/4.0/). 